\title{
Firm shutdown during the Financial and the Sovereign Debt crises: Empirical evidence from Portugal
}

\author{
Priscila Ferreira ${ }^{\dagger}$ \\ NIMA, University of Minho, Portugal \\ and \\ George Saridakis \\ SBRC, Kingston Business School, Kingston University, UK
}

\begin{abstract}
:
This paper examines Portuguese firms' survival over the business cycle and investigates whether the effect of firm size varies across the phases of the cycle and with the type of shock associated with the periods of economic contraction. Our results show that smaller firms are more likely to shut down than larger firms. Within each size band, however, we find that during the two crises micro firms experience hazards of closing (relative to large firms) at least similar to those observed in the pre-crisis period; while medium sized firms are found to be more vulnerable during the Financial Crisis period, but show more resilience during the Sovereign Debt Crisis. The results suggest that during the Sovereign Debt Crisis firms faced higher probability of closing than during the Financial Crisis.
\end{abstract}

Keywords: firm survival, SMEs, Financial Crisis, Sovereign Debt Crisis, Portugal

JEL classification: C33; J21; L25 


\section{INTRODUCTION}

The recent Financial Crisis made access to credit from banks more difficult and imposed financial constraints on Portuguese small and young firms (Iyer et al., 2014). It has been suggested that access to financing, credit extension and favourable lending options become less available to small and young firms during times of macroeconomic instability (McGuinness and Hogan, 2014; Cowling et al., 2015; Beck et al., 2008). As a consequence, the risk of such firms exiting the market increases, as predicted by the industrial economics theory of firm exit (e.g. Geroski et al., 2010; Caves, 1998; Everett and Watson, 1998; Mata and Portugal, 1994; Siegfried and Evans, 1994). Moreover, an erosion of market confidence compounded financial constraints making financial assistance from Troika (European Commission, European Central Bank and International Monetary Fund) essential to sustain the country's debt and prevent insolvency.

Credit constraints, on the one hand, are known to lower the innovation, growth and survival of small businesses in particular (e.g. Saridakis et al., 2013; OECD, 2012; Filippetti and Archibugi, 2011; Becchetti and Trovato, 2002; Geroski and Machin, 1993), which is the predominant firm size in Portugal (SMEs represent 99\% of all business population). It has also been argued that there is a differential response of firms in terms of growth and survival, depending on their access to capital and on their network structure. Furthermore, the fact that smaller firms lack control of their external environment (Storey and Sykes, 1996) and are more sensitive to funding and demand shocks than larger firms, also reduces their chances of survival (Holton et al., 2014; Mach and Wolken, 2012; Artola and Genre, 2011; Raz and Gloor, 2007; Berger and Udell, 2002; Gertler and Gilchrist, 1994). On the other hand, shocks to the banks' balance sheets and credit rating downgrades affect capital markets, interest rates and international relations. This is likely to affect larger firms' funding, international trade, investment and capital structure and hence their chances of growth and survival (e.g. Almeida et al., 2014; Claessens et al., 2012; Ivashina and Scharfstein, 2010; Lee et al., 2009; Liu, 2004).

The determinants of firm exit and survival have been widely studied in both management and economic literature (see, for example, Hyytinen et al., 2015; Bhattacharjee et al. 2007, Santarelli and Vivarelli, 2007; Agarwal and Gort, 2002, Robson, 1996). This paper, however, adds to the existing literature on firm survival in that we empirically investigate both the impact of the Financial Crisis (2008-09) and the Sovereign Debt Crisis (2010-11) on the survival of Portuguese firms, and examine whether this varies 
according to firm size. Previous research finds that small firms have higher exit rates than large firms (see, for example, DeTienne and Wennberg, 2016), but our paper attempts to distinguish the effect of the two economic shocks on different sized firms contrasting the pre-crisis period to the Financial Crisis and the Debt Crisis eras. This allows us to reveal potential strategic differences in the levels of resilience and adaptability by firm size. We expect that the effect of the Financial Crisis will be more detrimental on smaller firms than larger ones, as larger firms are better prepared to withstand contraction in market demand, can access alternative financial sources during lending contractions, and are more likely to hold foreign affiliations (hence scatter the risks). But as the Financial Crisis transformed into a Sovereign Debt Crisis and the country's risk premium increased, the vulnerability and exposure of large firms is also expected to increase (due to a decrease in the supply of credit to the country, trade shocks and balance sheet effects, for example).

The choice of Portugal as the country for analysis is based on the fact that while for most OECD countries the Great Recession relates to the economic contraction that followed the Global Financial Crisis (see van Ours, 2015), Portugal - similar to other GIIPS countries (Greece, Ireland, Italy, Portugal, Spain) - has not only experienced the economic contraction that the Financial Crisis precipitated, but also embarked on a fiscal consolidation programme to restore debt sustainability. Hence, Portugal offers a good setting to study the effect of different shocks on firm survival. Given that our analyses are focussed on the patterns of firm closure before and during the recent crises, we use data for the period between 2002 and 2012. ${ }^{1}$ The longitudinal employer-employee data used allows us to track firms over the study period and to control for characteristics of each firm and of its workforce.

Our results are interesting and shed more light on the importance of firm size on firm survival. We show that smaller firms are more likely to shut down than larger firms, with micro firms being nearly twice more likely to close down than large firms. This is quite a standard result within the existing empirical literature. Interesting results, however, are found when we distinguish between the two shocks. Specifically, we find that medium sized firms are more vulnerable during the Financial Crisis period, but show more resilience during the Sovereign Debt Crisis. In contrast, micro firms experience increasing rates of survival between the two crises. This result supports evidence from previous work in that smaller firms are able to adapt to recession conditions in ways (e.g. reducing salaries and working time, innovation) that enable them to survive (Bartz and Winkler, 2016; Lai et al., 2016; Smallbone et al., 2012; Kalbfleisch, 2006). Overall, although we 
find that the two crises led to an increase in the hazard rates of firm shutdown, firms faced higher probability of closing during the Sovereign Debt Crisis than during the Financial Crisis. To some extent, some of the shutdowns occurring in 2010 and after may be a consequence of the Financial Crisis of 2007-09, but during the austerity period market demand, economic growth, consumer confidence and access to bank financing suffered sharp declines putting further pressure to the firms' lifespan (Acharya et al., 2015; Ferrando et al., 2015; ECB, 2013). We also find that downsizing reduces the likelihood of survival. Hence, firms are called to adopt alternative structural reforms to address domestic market position, and improve their competiveness in global markets.

The paper is organised as follows. In Section 2, we provide a brief overview of the Portuguese economy. Section 3 describes the longitudinal linked employer employee data used, the Quadros de Pessoal from Portugal. In Section 4 we present our empirical strategy and econometric specification. Estimation results are presented in Section 5. Section 6 concludes the paper.

\section{OVERVIEW OF THE PORTUGUESE ECONOMY}

In the early 2000s, Portugal was reported as having high rates of labour force participation and low unemployment rates. This strong labour market performance was typically explained by flexible real wage adjustments and an expansion in the use of atypical contracts such as temporary and/or fixed term employment. The challenge to policymakers was to raise the income levels and increase competitiveness through the improvement of the productivity of the labour force by enhancing human capital and labour mobility. Lowskilled sectors were facing greater levels of competition from new EU members, suggesting that the economy needed to shift its production towards more highskilled/higher-value-added sectors (OECD, 2004).

Since 2006, however, the OECD reported concerns about rising unemployment in Portugal, and the need to prevent cyclical unemployment from becoming structural (OECD, 2010). More attention was drawn to restrictive employment protection legislation which acted as a barrier to labour mobility. Low levels of mobility encouraged firms to use fixed-term contracts which reduced incentives to provide training (OECD, 2006). The strategy adopted was to impose less restrictive employment legislation, in order to facilitate labour mobility, create jobs, and integrate job seekers back into work. This was 
expected to shorten unemployment spells and encourage firms to offer permanent contracts and provide training opportunities for their employees.

Although the Portuguese economy continued to grow after the burst of the Financial Crisis (see Pereira and Wemans, 2015), it had already started to show warning signs (e.g. low productivity growth, large budget and current accounts' deficits) of potential economic deterioration (Blanchard, 2007). Furthermore, given the economic and financial circumstances, between 2007 and 2009 banks imposed tighter credit constraints to non-financial firms (Artola and Genre, 2011), and Portuguese banks were not an exception. In April 2011, Portugal became the third Eurozone country (after Greece and Ireland) to receive a "bailout". Since 2008, one in seven jobs has been lost, the volume of productive investment has declined by over one third, average per capita income has declined over $10 \%$, the self-employment rate has decreased from $19 \%$ in 2007 to $16.8 \%$ in 2012, and the unemployment rate of young people exceeded 37\% in 2013 (ILO, 2014).

Using time series data for the Portuguese economy over the period 1995-2014 (Bank of Portugal, 2015) we dated the phases of the economic cycle. ${ }^{2}$ Figure 1 plots Portuguese GDP quarterly data (in million euros) for the period 1995 to 2014 and marks the turning points of the business cycle (left hand side axis); it also plots the evolution of the Diffusion Index on the banks' credit standards as applied to the approval of loans or credit lines to enterprises (right hand side axis). ${ }^{3}$ As can be seen, over the period of analysis the economic cycle shows three peaks: first quarter of 2002, first quarter of 2008 and third quarter of 2010 (2002q1, 2008q1, and 2010q3); and 3 troughs (2003q2, 2009q1, and 2012q4). Specifically, the first phase of economic contraction $(2002 q 1-2003 q 2)$ is associated to the dot-com crisis. The second phase of economic contraction (2008q1 2009q1) relates to the Global Financial Crisis. This was accompanied by a strong tightening of the standards for credit supply (more positive Diffusion Index). The phase of economic expansion that followed is likely to be due to the conjuncture measures of "The European Economic Recovery Plan" [EERP] of November 2008 aimed at controlling the effects of the Financial Crisis. The EERP had two pillars: (i) a major injection of purchasing power into the economy, to boost demand and stimulate confidence (European Commission, 2008: p. 2) and (ii) short-term actions to reinforce long-term competition through strategic investments, and other measures to support product- and labour-markets. In summary, the EERP proposed "a counter-cyclical macro-economic response to the crisis in the form of an ambitious set of actions to support the real economy. The aim is to avoid a deep recession." (EC, 2008: p. 6). Despite the overall aim of the EERP the Portuguese 
economy experienced a severe economic contraction between $2010 q 3-2012 q 4$, as a result of the European Sovereign Debt Crisis of late 2009 (for details on the European Sovereign Debt Crisis see, e.g. Lane, 2012). The phase of economic contraction associated to the Sovereign Debt Crisis was also accompanied by increased credit constraints.

[Figure 1 about here]

During the Great Recession there was a massive exit of firms from the market and net firm destruction in the Portuguese economy. We use Eurostat's (2015) data on firms' births and deaths for the period 2004-2014 to describe the demography of all active Portuguese firms (regardless of having registered employees). ${ }^{4}$ Figure 2 shows the patterns of firm entry and exit between 2004 and 2013. As the Figure shows, firm creation is more cyclical than firm exit. ${ }^{5}$ Furthermore, until 2008 there was net firm creation in the country, as the number of firm births outweighed the number of firm deaths. The stock of firms in the Portuguese economy, however, started to decline from 2008 onwards. The number of firm births was severely reduced until 2010, while the number of firm deaths remained at high levels. Given the severe fluctuation in economic activity during crisis, in the presence of entry costs, the exit of firms is likely to have a lasting effect on the number of active firms and permanent negative effects on productivity (van Ewijk, 1997).

Our main interest lies in the hazard of firm shutdown, and we are particularly interested in identifying whether the effect of firm size varies not only over the business cycle, but also with the type of shock (Financial Crisis, Sovereign Debt Crisis) that leads to the phases of economic contraction.

[Figure 2 about here]

\section{DATA}

The data used in this study are from the Quadros de Pessoal (QP) from Portugal. This is a longitudinal data set with matched information on workers and firms from 2002 to 2012 . $^{6}$ The Portuguese Ministry of Employment has collected the data annually since 1985 and the participation of firms with registered employees is compulsory by law. The survey is administered in October, and filled in by the firms. Furthermore, firms are required to have 
the survey available for public consultation, which ensures an unusual level of data coverage and accuracy. The data include all firms (over 250,000 per year) and employees (more than two million per year) within the Portuguese private sector. Each firm and each worker has a unique registration number, which allows them to be traced over time. We restrict our analysis to manufacturing and services, and the resulting sample is composed of 544,645 unique firms contributing to 2,818,631firm-year observations over the period. ${ }^{7}$ Our data does not explicitly identify firm closures. We assume that firms exit the market when they are last observed in the data. Hence the variable reporting a firm's death takes the value 1 in year $t$ if the firm is last observed that year, and 0 otherwise. ${ }^{8}$

In Table 1 we provide a brief description of the sample size and rates of firm shutdown by year. Both the stock of firms in each year and the proportion of firms dying between two time periods reveal the effects of the Great Recession. For example, in column (i) we find that the number (stock) of private sector firms in the economy initially rises from 234,340 firms in 2002 to 283,260 in 2008. In 2009 there was net destruction of about 8,000 firms with the stock of active companies being 275,594 . The number of firms shutting down between $t$ and $t+1$ as a proportion of the number of firms in year $t$ ranged from nearly $10 \%$ in the first half of the decade to $20 \%$ in 2009 and 17\% in 2011 (column ii). Since the onset of the Global Financial Crisis, there was net reduction in the stock of firms in the Portuguese economy, and the number of active firms in 2012 was the lowest observed over the period of analysis. ${ }^{9}$

[Table 1 about here]

\section{ECONOMETRIC SPECIFICATION}

We analyse the determinants of the risk of firm shutdown by estimating duration models of the probability of firm shutdown in $t+1$ conditional on survival up to time t. The key focus in this analysis is on whether, and if so how, the impact of firm size changed during the recent crises. We estimate the hazard rate of firm shutdown between two consecutive years $(\mathrm{t}$ and $\mathrm{t}+1)$ using a discrete time multivariate proportional hazards approach. In particular, we apply a complementary log-log model with firm-specific random effects (Jenkins, 2005). ${ }^{10}$ The nature of our data implies that we have an inflow sample with left truncation and right censoring. That is, we include in our sample all firms existing in 2002 plus firms that were created between 2002 and 2011, and we observe only a proportion of them 
shutting down over the period. Because information on the year the firm was created is available in our data, we are able to model the time dependence of the risk of closing. In other words we can model the correlation between the probability of firm shutdown and the age of the firm (see Jovanovic, 1982). We do this using a non-parametric baseline hazard rate identified by duration-interval-specific dummy variables. We allow the baseline hazard rate to vary yearly up to the $50^{\text {th }}$ year of survival of the firm. We assume the hazard to be constant thereafter.

The hazard rate $\mathrm{h}(\mathrm{t})$ is conditional on a range of observed covariates ( $\mathrm{x}$ ) as well as firm survival $(\mathrm{t})$, such that

$$
h(t)=\operatorname{Pr}\left(T=t_{j} \mid T \geq t_{j} ; x\right) .
$$

We assume that firm $\mathrm{j}$ shuts down between $\mathrm{t}$ and $\mathrm{t}+1$ with probability $\operatorname{Pr}\left(\mathrm{y}_{\mathrm{jt}}=1\right)=\lambda_{\mathrm{j}}$ and that it survives with probability $\operatorname{Pr}\left(\mathrm{y}_{\mathrm{jt}}=0\right)=1-\lambda_{\mathrm{j}}$. We further assume that this probability is a function of covariates $(x)$ and of an unobserved firm-specific effect $\left(\psi_{j}\right)$, such that the hazard rate can be expressed by the following:

$$
\lambda_{\mathrm{jt}}=\beta_{0}+\beta_{1} \mathrm{x}_{1 \mathrm{jt}}+\beta_{2} \mathrm{x}_{2 \mathrm{jt}}+\ldots+\beta_{\mathrm{k}} \mathrm{x}_{\mathrm{kjt}}+\psi_{\mathrm{j}}
$$

Although our underlying continuous time model is summarized by the hazard rate $h(t)$, our data is interval-censored (that is, we do not know the exact date when a firm closes). Therefore, we estimate the parameters describing the hazard rate taking into account the discrete nature of the duration data using a complementary log-log specification

$$
\log \left[-\log \left(1-\lambda_{\mathrm{jt}}\right)\right]=\beta_{0}+\beta_{1} \mathrm{x}_{1 \mathrm{jt}}+\beta_{2} \mathrm{x}_{2 \mathrm{jt}}+\ldots+\beta_{\mathrm{k}} \mathrm{x}_{\mathrm{kjt}}+\psi_{\mathrm{j}}
$$

This implies

$$
\hat{\lambda}_{\mathrm{jt}}=1-\mathrm{e}^{-\mathrm{e}^{\hat{\beta}^{\prime} \mathrm{X}_{\mathrm{jt}}}}
$$

where $\hat{\lambda}_{\mathrm{jt}}$ is the estimated hazard rate of firm shutdown conditional on the vector of observed characteristics $(\mathrm{X})$ that includes: the firm's size (micro, small, medium, large) ${ }^{11}$, ownership of the firm (whether private-national, public, or foreign owned), natural log of the firm's sales volume (in real terms) and the legal form of the firm (whether quota society, individual name, unipersonal quota society, anonymous society or other), industry (17 industries), region (North, Algarve, Centre, Lisbon, Alentejo, and Islands). ${ }^{12}$ We also control for aggregate characteristics of the labour force to account for human capital 
accumulation (mean seniority, mean potential labour market experience, proportion of workers that have university degrees, and proportion of high-skilled workers ${ }^{13}$ ), and for the stability of workforce, since a more stable workforce is likely to accumulate more firmspecific human capital and, consequently, be more productive (proportion of women, mean age of the workforce, proportion of fixed-term contracts and of part-time workers). As discussed previously, time dependence is captured by a set of variables indicating the firm's age. Descriptive statistics of the explanatory variables are shown in Table 2 below. ${ }^{14}$

[Table 2 about here]

\section{ESTIMATES OF HAZARDS OF FIRM-SHUTDOWN}

\subsection{Main results}

In this section we examine whether the effect of firm size varies over the business cycle and with the type of shock associated to the phase of economic contraction. To this end, we construct a time index to separate the pre-crisis period (2002-2007) from the Financial Crisis period (2008-2009) and the Sovereign Debt Crisis period (2010-2011), although the two crises are interrelated. We then estimate a model that allows the impact of size to vary before and during the crisis, using a specification where size is interacted with the time indicator variable. Because firm size is a dynamic concept (labour is a variable production factor) we have identified the firm's modal size category to ensure that each firm

contributes to one size category alone. ${ }^{15}$ Yet, we also estimate model specifications that consider the firms' contemporaneous size, and these results are presented as robustness tests in the next section.

Estimates of the hazard of firm shutdown are presented in Table 3 for the whole sample, and in Table 4 for the sample split into sub-periods (pre-crisis and crisis). We report hazard ratios which summarise the proportional effect on the hazard rate of a one unit change in the covariates, such that a hazard ratio above (below) one implies a proportionate increase (decrease) in the probability of a firm closing.

Estimates using the full sample are presented in Table 3. In column (1) of Table 3, we present a basic model that, besides the set of covariates mentioned above, includes only the main effects of the firm (modal) size categories and the time periods. The next three columns of Table 3 include interaction terms between firm (modal) size and time period. In column (2) we include the following period indicators: Financial Crisis (2008-2009) and 
Debt Crisis (2010-2011) as covariates, the omitted category is the pre-crisis period; in column (3) we include one period indicator: Financial Crisis (2008-2009), all other periods are included in the baseline; in column (4) we include one period indicator: Debt Crisis (2010-2011), the other two periods are omitted.

[Table 3 about here]

Results in Table 3 show that, in general, smaller firms are more likely to shut down than larger firms. In particular, the hazard of firm shutdown is found to be nearly two times larger for micro firms relative to larger firms. As firm size increases, the hazard ratio declines: small firms have between $25 \%$ and $35 \%$ higher hazard rates of shutdown as larger firms, whereas the medium sized firms are only $18 \%$ more likely to go out of business. These results can be partly understood under the Schumpeterian competition model of Nelson and Winter (1982). Large firms have more resources to withstand competitive pressures and demand shocks, and spend more in R\&D than small firms. This may increase their chances of finding a better technology that will induce productivity gains and contribute to further firm growth (Cefis and Marsili, 2005). The productivity gains make it profitable for firms to hire more workers as long as they have a market that absorbs the increases in production. Because large firms can exploit a new technology on a relatively large scale they adopt new technology more quickly, which increases their chances of survival compared to smaller firms (Kepler and Simons, 2000). Additionally, large firms are required to disclose financial information related to payment practices and performance (Storey, 1994), thus minimising information asymmetries and monitoring costs. In contrast, financial reports produced by small firms are relatively simple and mainly for tax purposes (Tsaih et al., 2004) and not readily available to financial institutions (e.g. banks) when seeking funding to finance investment and sustain growth (see Fraser et al., 2015). Furthermore, large firms have greater assets (which can be used as collateral) than small firms and thus, are more likely to be charged lower rates when borrowing and are less likely to experience loan rejection and discouragement (Saridakis and Storey, 2009).

In column (2) of Table 3 we report the coefficients of the financial and sovereign debt crises dummies and their interactions with firm (modal) size. The time period dummy variables are found to be individually and jointly (Wald test statistic of 35.66 with a pvalue of 0.00 ) statistically significant. ${ }^{16}$ In particular, we find that during the Financial 
Crisis firms have higher hazard of closing down than in the pre-crisis period, and the risk was slightly higher in the years of Sovereign Debt Crisis (the hazard ratio ranges from 2.00 in the Financial Crisis to 2.09 in the Debt Crisis). When the crises dummies are interacted with firm (modal) size, we find that the relative risk of shutdown differs only between medium sized firms and large firms during the Financial Crisis period. ${ }^{17}$ Specifically, medium sized firms are found to have around $29 \%$ higher hazard rate of shutdown than larger firms. This can be partly explained by difficulties in access to credit. Indeed during the two crises, loans to SMEs have decreased substantially and interest rates on new loans have increased nearly 2 percentage points between 2010 and 2012 (ILO, 2014), with 21\% of the Portuguese firms reporting access to finance as a major obstacle in their business operations (ECB, 2013). Additionally, we can argue that medium sized firms usually operate under a structure similar to that of large firms (see Storey et al., 2010) and face similar problems, but have fewer resources available to overcome them. In contrast, micro and smaller firms are able to respond flexibly and operate under fewer structural constraints (Smallbone et al., 2012). Similar results emerge when we estimate the model including each crisis dummy at a time. ${ }^{18}$

Table A4 in the appendix reports the coefficients of a few other covariates used as controls in our specifications. Our results suggest that firms with larger sales volumes ${ }^{19}$, public and foreign owned firms, as well as multi-plant firms have a lower risk of closing. These firms are probably more likely to have stronger market positions and greater scope for strategic choices and (internal and external) alliances to withstand economic crises, thus increasing their chances of survival. Quota societies have significantly lower hazards of shutdown than firms based on other legal forms. Regarding the aggregate characteristics of the labour force, we conclude that our proxies for human capital accumulation (see Bosma et al., 2004; Bruderl et al., 1992) and proxies for the stability of the labour force are important determinants of firms' survival rates. For example, firms with greater proportions of university graduates and where the workers have higher mean labour market experience and seniority at the firm have lower hazards of shutting down. On the other hand, firms with greater intensity of fixed-term contracts, part-time workers, foreign nationals, and older workers have greater probabilities of closing.

Additionally, Figure 3 illustrates how the predicted risk of firm shutdown evolves with the age of the firm and reveals the nature of duration dependence. We find that the hazard of firm shutdown is generally declining with time (negative duration dependence). However, the rate at which the hazard declines over time is not constant. In the first four 
years the risk of firm closure is very high and declines only marginally (hazard rate of about 1.6 between the second and fourth years of age). ${ }^{20}$ The hazard steadily declines between the $5^{\text {th }}$ and $20^{\text {th }}$ year that a firm is in the market, and remains relatively constant thereafter (at about 0.8). In Table A5 in appendix we report the mean predicted hazards by firm size and time period.

[Figure 3 about here]

In Table 4 we present sub-sample estimates of the hazard of firm closures, the parameterization of each of the columns in the Table is as follows: in column (1) we consider only observations of the pre-crisis period (2002-2007), and include indicators of firm size; in columns (2) and (3) the crisis period is considered (2008-2011). In column (2) we include indicators for size and time period (omitted category is the 2008-2009 Crisis); in column (3) we further add terms on the interaction of firm size and time period.

[Table 4 about here]

Results in Table 4 also suggest that smaller firms have higher hazard rates of closing than larger firms (similar to the results obtained in Table 3). However, the hazard of closing for micro firms is lower during the crises periods than in the pre-crisis period, whereas it increases for small and medium sized firms (contrast coefficients of firm size in columns (2) and (3) to those in column (1)). ${ }^{21} \mathrm{We}$ also find that, on average, firms have $4 \%$ higher risk of going out of business during the Sovereign Debt Crisis than during the Financial Crisis (hazard ratios of the time period dummy of 1.04 in column (2)). When the Sovereign Debt Crisis dummy interacts with the firm size, only the firm size coefficients remain significant.

\subsection{Robustness checks}

Results in the previous section suggest that the risk of firms' shutting down declines with firm size, and that medium sized firms have an increased risk of closing during the Financial Crisis. We also find evidence that firms are more likely to close during the Sovereign Debt Crisis than during the Financial Crisis - during the crisis period, the hazards of shutdown of small and medium sized firms are higher than those of the pre- 
crisis period, while the hazards of shutdown of micro firms is similar in the pre-crisis and the crisis period. All the results discussed earlier are obtained considering the firms' modal size. In this Section we report robustness results to using alternative measures of firm size. We re-estimate the model specifications of Tables 3 and 4 using the firms' contemporaneous size category alone; and using the contemporaneous size category along with controls for changes in employment at the firm level. ${ }^{22}$ These results are presented in Table 5. The first four columns of Table 5 relate to a specification with controls for the firms' contemporaneous size alone and columns (5)-(8) relate to the results when we add as control the change in employment at the firm level. Within each set of columns the structure of Table 5 resembles that of Table 3.

Results in Table 5 suggest that the best fitting model (largest log likelihood) is the one where controls for year-on-year changes in employment are included. Hence, we will focus our discussion on the results reported in columns (5)-(8). ${ }^{23}$ Downsizing through layoffs is usually seen as a strategy to survive during times of economic hardship (see Cascio, 1993). Also, in a recession, large firms are more likely than SMEs to downsize (Lai et al., 2016). Here we find that firms that reduce their number of employees can have $26 \%$ larger hazard of shutdown than firms who kept a stable workforce; on the other hand, the hazard of closing for firms that are growing in terms of number of employees is only 0.65 that of the hazard of firms who do not do so. For all other variables, estimates in Table 5 generally reinforce those obtained in the previous section. The hazard of shutdown of micro firms is around 2.4 to 2.7 times that of large firms and as firm size increases the hazard ratio declines. We also confirm that the risk of closing is higher during the Financial Crisis than in the pre-crisis period, and the risk was even higher in the years of the Sovereign Debt Crisis (the hazard ratio ranges from 1.97 in the Financial Crisis to 2.08 in the Debt Crisis, column (6)). When the crises' dummies are interacted with firm size, we find evidence that the relative risk of shutdown differs only between medium sized firms and large firms during the Financial Crisis period (columns (2), (3) and (7). ${ }^{24}$

\section{[Table 5 about here]}

In Table 6 we present sub-sample estimates of the hazard of firm closures as per Table 4, but using contemporaneous firm size (columns (1)-(6)) and controls for firm-level changes in employment (columns (4)-(6)). Yet again, results reinforce those obtained previously. Micro firms have similar relative risk of shutdown before and during crises. On 
the other hand, the risk of closing for small and medium sized firms is larger during the crises periods than in the pre-crisis period (contrast coefficients of firm size in columns (5) and (6) to those in column (4)). ${ }^{25}$ Results in Table 6 also support the finding that firms face a higher probability of going out of business during the Sovereign Debt Crisis rather than during the Financial Crisis (hazard ratio of the time period dummy of 1.02, column (5). When the Sovereign Debt Crisis dummy interacts with the firm size, we find that medium sized firms have lower hazard rate of closing than large organizations (hazard ratio of 0.73 , column (3)). This can be due to the fact that larger firms are more likely to be exposed to international economy and lay off (talented) workers who can then seek employment in smaller firms with growth potential (Lai et al., 2016; Saridakis, 2012). ${ }^{26}$

[Table 6 about here]

\section{CONCLUSIONS}

This paper has analysed a panel of linked employer-employee data from Portugal to empirically investigate whether the effect of firm size varies over the business cycle and with the shocks from the Financial Crisis and the Sovereign Debt Crisis. Although the two crises are interrelated, their effects are found to be different in nature and received different policy responses. We find a number of key results. First, smaller firms are more likely to shut down than larger firms, with micro firms being nearly twice more likely to shutdown than large firms. Second, micro firms are found to experience higher hazard rates of closing during the pre-crisis period than during crisis period. Third, this is not the case for larger sized firms for whom the closure rate is found to increase during the recession. The reasons for this are not reported in the data, but may be postulated. Micro firms, for example, are less exposed to foreign financial markets and risks, are less dependent on bank credit, and their HR procedures are more discretionary and flexible compared with larger firms. These factors allow micro firms to work more flexibly, rather than undertake structural shifts, and adapt to recession conditions in such a way that enables them to survive (Cowling et al., 2015; Smallbone et al., 2012; Reid, 2007; Grewal and Tansuhaj, 2001; and Hitt, et al., 1998). Fourth, we find that medium sized firms were more vulnerable during the Financial Crisis period than large firms, but showed more resilience during the Sovereign Debt Crisis. Finally, the results suggest that the Sovereign Debt Crisis had higher impact on the risk of firm shutdown than the Financial Crisis. 
The above analysis raises important questions and provides strategic options for interventions both by entrepreneurs and policy makers. Small and medium sized firms may seek to build financial resilience and capabilities to cope with challenging and prolonged environmental shocks (see also Smallbone et al., 2012). This can be done, for example, by reducing their dependence on conventional sources of external funding from financial institutions and cost-cutting measures when facing distress. In particular, small firms may be proactive and exploit new market opportunities, such as through foreign alliances, and adjust their product/service portfolio, business and labour market strategies to minimise risk and sustain competitive advantage to withstand times of economic turmoil and instability. Also, downsizing as management strategy may not be a panacea when a firm is in decline. Downsizing may affect firm internal functioning (e.g. increase employees' job insecurity and damage motivation and commitment), provide signs of performance deterioration to the external environment (e.g. customers, creditors) and generally weaken a firm's strategic and competitive position in the marketplace. Given the magnitude of the shocks and the rate of firm exits, the economy is unlikely to be able to return to its original productivity growth path by itself (van Ewijk, 1997), hence there is room for public policy intervention. Policy makers may seek to encourage strategic changes and innovation within small organisations, and support innovation and new business ideas to help businesses mitigate the impact of recession (for detailed discussion, see Kitching et al., 2009).

Additionally, the unevenness of the impact of the sovereign and financial crises suggests that policy needs to be more attuned to help ameliorate the effects of specific crises rather than mere 'blanket' approaches. The uneven effects on firms of different sizes also suggest a need for some fine-tuning of interventions depending on firm size. This will inevitably involve both fiscal and monetary strategic interventions. It is questionable, however, whether the fiscal consolidation and expenditure cuts are appropriate or else they may lead to the medicine being worse than the actual economic malaise. This is an issue that deserves future research. 


\section{Acknowledgements}

We are grateful to two anonymous referees for valuable comments and suggestions. We also thank Robert Blackburn, John Kitching and participants at the $28^{\text {th }}$ annual conference of the European Society of Labour Economists [EALE], the $30^{\text {th }}$ annual conference of the European Society for Population Economics (ESPE), and the 2016 Institute for Small Business and Entrepreneurship (ISBE) conference for useful comments and discussions. 


\section{References}

Acharya, V. V., T. Eisert, C. Eufinger and C. Hirsch. 2014. "Real effects of the Sovereign Debt Crisis in Europe: evidence from syndicated loans." CEPR Discussion Paper No. 10108.

Agarwal, R. and M. Gort. 2002. "Firm and product life cycles and firm survival." American Economic Review 92(2): 184-90.

Almeida, H., I. Cunha, M. Ferreira, and F. Restrepo. 2014. "The real effects of sovereign credit rating downgrades." LSE unpublished paper.

Artola, C. and V. Genre. 2011. "Euro Area SMEs under financial constraints: belief or reality?" CESIFO Working Paper No. 3650.

Bank of Portugal. 2013. Bank Lending Survey - results for Portugal. Online at: http://www.ecb.europa.eu/stats/money/surveys/lend/html/index.en.html.

Bank of Portugal. 2015. BPstats - online statistics. Online at:

https://www.bportugal.pt/EstatisticasWeb.

Bartz, W. and A. Winkler. 2016. "Flexible or fragile? The growth performance of small and young businesses during the global Financial Crisis — Evidence from Germany." Journal of Business Venturing 31(2): 196-215.

Becchetti, L. and G. Trovato. 2002. "The determinants of growth of small and medium sized firms: the role of the availability of external finance." Small Business Economics 19(4): 291-306.

Beck, T., A. Demirgüç-Kunt, L. Laeven and R. Levine. 2008. "Finance, firm size, and growth." Journal of Money, Credit and Banking 40(7): 1379-1405.

Berger, A. N. and G. F. Udell. 2002. "Small business credit availability and relationship lending: the importance of bank organisational structure." Economic Journal 112(477): F32-F53.

Bhattacharjee, A., C. Higson, S. Holly and P. Kattuman. 2007. "Macroeconomic instability and business exit: determinants of failures and acquisitions of UK firms." Economica 76(301): 108-131.

Blanchard, O. 2007. "Adjustment within the euro: the difficult case of Portugal." Portuguese Economic Journal 6(1): 1-21.

Bosma, N., M. van Prag, R. Thurik and G. de Wit. 2004. "The value of human and social capital investments for the business performance of startups." Small Business Economics 23(3): 227-236.

Bracke, P. 2011. "SBBQ: Stata module to implement the Harding and Pagan (2002) business cycle dating algorithm", Software component, Boston College Department of Economics, Statistical Software Components Series No. S457288. 
Bruederl, J., P. Preisendoerfer and R. Ziegler. 1992. "Survival chances of newly founded business organizations." American Sociological Review 57(2): 227-242.

Bry, G. and C. Boschan. 1971. "Cyclical analysis of time series: selected procedures and computer programs." NBER Technical Paper No. 20

Cascio, W. 1993. "Downsizing: What do we know? What have we learned?" Executive 7(1): 95-104.

Caves R. E. 1998. "Industrial organization and new findings on the turnover and mobility of firms." Journal of Economic Literature 36(4): 1947-1982.

Cefis, E. and O. Marsili. 2005. "A matter of life and death: innovation and firm survival." Industrial and Corporate Change 14(6): 1167-1192.

Claessens, S., H. Tong and S. J. Wei. 2012. "From the Financial Crisis to the real economy: Using firm-level data to identify transmission channels." Journal of International Economics 88(2): 375-387.

Cowling, M., W. Liu, A. Ledger and N. Zhang. 2015. "What really happens to small and medium-sized enterprises in a global economic recession? UK evidence on sales and job dynamics." International Small Business Journal 33(5): 488-513.

DeTienne, D. and K. Wennberg. 2016. "Studying exit from entrepreneurship: New directions and insights." International Small Business Journal 34(2): 151-156.

European Central Bank. 2013. "Confidence indicators and economic developments." Monthly Bulletin (January): 45-58.

European Commission. 2008. "Communication - A European Economic Recovery Plan." $\operatorname{COM}(2008) 800$ final. Brussels.

Eurostat. 2015. "Structural Business Statistics - Business Demography." Online at: http://ec.europa.eu/eurostat/web/structural-business-statistics/entrepreneurship/businessdemography.

Everett, J. and J. Watson. 1998. "Small business failure and external risk factors." Small Business Economics 11(4): 371-390.

Ferrando, A., A. Popov and G. F. Udell. 2015. "Sovereign stress, unconventional monetary policy, and SME access to finance." ECB Working Paper Series No. 1820.

Filippetti, A. and D. Archibugi. 2011. "Innovation in times of crisis: National Systems of Innovation, structure, and demand." Research Policy 40(2): 179-192.

Fraser, S., S. K. Bhaumik and M. Wright. 2015. "What do we know about entrepreneurial finance and its relationship with growth?" International Small Business Journal 33(1): 7088. 
Geroski, P., J. Mata and P. Portugal. 2010. "Founding conditions and the survival of new firms." Strategic Management Journal 31(5): 510-529.

Geroski, P. and S. Machin. 1993. "Innovation, profitability and growth over the business cycle." Empirica 20(1): 35-50.

Gertler, M. and S. Gilchrist. 1994. "Monetary policy, business cycles, and the behaviour of small manufacturing firms." Quarterly Journal of Economics 109(2): 309-340.

Grewal, R. and P. Tansuhaj. 2001. "Building organisational capabilities for managing economic crisis: the role of market orientation and strategic flexibility." Journal of Marketing 65(2): 67-80.

Harding, D. and A. Pagan. 2002. "Dissecting the cycle: a methodological investigation." Journal of Monetary Economics 49(2): 365-381.

Hitt, M. A., B. W. Keats and S. M. DeMarie. 1998. "Navigating in the new competitive landscape: building strategic flexibility and competitive advantage in the 21st Century." Academy of Management Executive 12(4): 22-42.

Holton, S., M. Lawless and F. McCann. 2014. "Firm credit in the euro area: a tale of three crises." Applied Economics 46(2): 190-211.

Huynh, K., and R. Petrunia. 2016. "Post-entry struggle for life and pre-exit shadow of death from a financial perspective." International Journal of the Economics of Business 23(1): 1-18.

Huynh, K. P., R. J. Petrunia and M. C. Voia. 2012. "Initial Financial Conditions, Unobserved Heterogeneity and the Survival of Nascent Canadian Manufacturing Firms." Managerial and Decision Economics 33(2): 109-125.

Huynh, K. P., R. J. Petrunia and M. C. Voia. 2010. "The impact of initial financial state on firm duration across entry cohorts." Journal of Industrial Economics 58(3): 661-689.

Hyytinena, A., M. Pajarinenb and P. Rouvinenb. 2015. "Does innovativeness reduce startup survival rates?" Journal of Business Venturing 30(4): 564-581.

International Labour Organization. 2014. "Studies on growth with equity: tackling the job crisis in Portugal."

Ivashina, V. and D. Scharfstein. 2010. "Bank lending during the Financial Crisis of 2008." Journal of Financial Economics 97(3): 319-338.

Iyer, R., S. Lopes, J-L Peydro, and A. Schoar. 2014. "Interbank liquidity crunch and the firm credit crunch: evidence from the 2007-2009 crisis." Review of Financial Statistics 27(1): 347-372.

Jenkins, S. P. 2005. Survival Analysis. Institute for Social and Economic Research, University of Essex, Colchester, UK: Unpublished manuscript. 
Jovanovic, B. 1982. "Selection and the evolution of industry." Econometrica 50(3): 649670.

Kalckreuth, V. U. 2006. "Financial constraints and capacity adjustment: evidence from a large panel of survey data." Economica 73(292): 691-724.

Klepper, S. and K. Simons. 2000. "The making of an oligopoly: firm survival and technological change in the evolution of the US tire industry." Journal of Political Economy 108(4): 728-60.

Kitching, J., R. Blackburn, D. Smallbone and S. Dixon. 2009. "Business strategy and performance during difficult economic conditions." Business Innovation and Skills, URN 09/1031.

Lai, Y., G. Saridakis, R. Blackburn and S. Johnstone. 2016. "Are the HR responses of small firms different from large firms in times of recession?" Journal of Business Venturing 31(1): 113-131.

Lane, P. R. 2012. "The European Sovereign Debt Crisis." Journal of Economic Perspectives 26(3): 49-67.

Lee, Y. and T. Mukoyama. 2015. "Entry and exit of manufacturing plants over the business cycle." European Economic Review 77: 20-27.

Lee, S.-H., P. W. Beamish, H.-U. Lee and J.-H. Park. 2009. "Strategic choice during economic crisis: Domestic market position, organizational capabilities and export flexibility." Journal of World Business 44(1): 1-15.

Liu, J. 2004. "Macroeconomic determinants of corporate failures: evidence from the UK." Applied Economics 36(9): 939-45.

Mach, T. L. and J. D. Wolken. 2012. "Examining the impact of credit access on small firm survivability." in Small Businesses in the Aftermath of the Crisis: International Analysis and Policies edited by Giorgio Calcagnini and Ilario Favaretto, 189-210. Heidelberg: Physica-Verlag.

Mata, J. and P. Portugal. 1994. "Life duration of new firms." Journal of Industrial Economics 42(3): 227-245.

McGuinness, G. and T. Hogan. 2014. "Bank credit and trade credit: Evidence from SMEs over the Financial Crisis." International Small Business Journal 34(4): 412-445.

Nelson, R. R. and S. G. Winter. 1982. An Evolutionary Theory of Economic Change, Cambridge MA: Belknap Press of Harvard University Press.

OECD. 2012. "Financing SMEs and Entrepreneurs 2012: An OECD Scoreboard." Paris: OECD Publishing.

OECD. 2010. "OECD Economic Surveys: Portugal 2010." Paris: OECD Publishing. 
OECD. 2006. "OECD Economic Surveys: Portugal 2006." Paris: OECD Publishing.

OECD. 2004. "OECD Economic Surveys: Portugal 2004." Paris: OECD Publishing.

Pakes, A. and R. Ericson. 1998. "Empirical implications of alternative models of firm dynamics." Journal of Economic Theory 79(1): 1-45.

Pereira, P. T. and L. Wemans. 2015. "Portugal and the global Financial Crisis: shortsighted politics, deteriorating public finances and the bailout imperative." in The Global Financial Crisis and its Budget Impacts in OECD Nations: Fiscal Responses and Future Challenges edited by John Wanna, Evert A. Lindquist and Jouke de Vries, 231-254. Cheltanham, UK: Edward Elgar.

Raz, O. and P. A. Gloor. 2007. "Size really matters - New insights for start-ups' survival." Management Science 53(2): 169-177.

Reid, G. 2007. The Foundations of Small Business Enterprise: An Entrepreneurial Analysis of Small Firm Inception and Growth. London: Routledge.

Ronson, M. T. 1996. "Macroeconomic factors in the birth and death of UK firms: evidence from quarterly VAT registrations." Manchester School 64(2): 170-88.

Saridakis, G., K. Mole and G. Hay. 2013. "Liquidity constraints in the first year of trading and firm performance." International Small Business Journal 31(5): 520-535.

Saridakis, G. 2012. "Introduction to the special issue on enterprise activity, performance and policy during times of crisis." International Small Business Journal 30(7): 733-735.

Saridakis, G. and D. Storey. 2009. "UK SMEs and bank finance." in Financing enterprises: Basel 2 and the changes induced in knowledge, competence and bankenterprise relationship edited by Giuseppe D'Angelo and Adriano Giannola, 87-102. Napoli, Italy: Liguori Editore.

Siegfried, J. J. and L. B. Evans. 1994. "Empirical studies of entry and exit: a survey of the evidence." Review of Industrial Organization 9(2): 121-55.

Smallbone, D., D. Deakins, M. Battisti and J. Kitching. 2012. "Small business responses to a major economic downturn: Empirical perspectives from New Zealand and the United Kingdom." International Small Business Journal 30(7): 754-777.

Storey, D. J., G. Saridakis, S. Sen-Gupta, P. K. Edwards and R. A. Blackburn. 2010. "Linking HR formality with employee job quality: the role of firm and workplace size." Human Resource Management 49(2): 305-329.

Storey, D. J. and N. S. Sykes. 1996. "Uncertainty, innovation and management." in Small Business and Entrepreneurship, edited by P. Burns and Jim Dewhurst, 73-93. London: Palgrave.

Storey, D. J. 1994. Understanding the Small Business Sector. London: Routledge. 
Tsaih, R., Y. Liu, W. Liu and Y. Lien. 2004. "Credit scoring system for small business loans." Decision Support Systems 38 (1): 91-99.

van Ewijk, C. 1997. "Entry and exit, cycles, and productivity growth." Oxford Economic Papers 49(2): 167-187.

van Ours, J. 2015. "The Great Recession was not so great." Labour Economics 34: 1-12.

Varum, C. and V. Rocha. 2012. "The effect of crises on firm exit and the moderating effect of firm size." Economics Letters 114(1): 94-97. 


\section{Tables}

Table 1: Distribution of firms and death rates over the period, 2002-2011

\begin{tabular}{|c|c|c|c|c|c|c|c|c|c|c|}
\hline \multirow[b]{2}{*}{ Year } & \multicolumn{2}{|c|}{ All firms } & \multicolumn{2}{|c|}{ Micro } & \multicolumn{2}{|c|}{ Small } & \multicolumn{2}{|c|}{ Medium } & \multicolumn{2}{|c|}{ Large } \\
\hline & $\begin{array}{l}\mathrm{Nb} . \\
\text { firms } \\
(1)\end{array}$ & $\begin{array}{c}\% \\
\text { Shut } \\
\text { down } \\
(2)\end{array}$ & $\begin{array}{l}\mathrm{Nb} . \\
\text { firms } \\
(3)\end{array}$ & $\begin{array}{c}\% \\
\text { Shut } \\
\text { down } \\
(4)\end{array}$ & $\begin{array}{l}\mathrm{Nb} . \\
\text { firms } \\
(5)\end{array}$ & $\begin{array}{c}\text { \% Shut } \\
\text { down } \\
\text { (6) }\end{array}$ & $\begin{array}{l}\mathrm{Nb} . \\
\text { firms } \\
(7)\end{array}$ & $\begin{array}{c}\% \\
\text { Shut } \\
\text { down } \\
(8)\end{array}$ & $\begin{array}{l}\mathrm{Nb} . \\
\text { firms } \\
(9)\end{array}$ & $\begin{array}{c}\% \text { Shut } \\
\text { down } \\
(10)\end{array}$ \\
\hline 2002 & 234,340 & 9.79 & 189,864 & 11.10 & 37,943 & 4.47 & 5,736 & 2.67 & 797 & 2.13 \\
\hline 2003 & 243,531 & 9.11 & 198,250 & 10.28 & 38,460 & 4.09 & 5,986 & 3.32 & 835 & 2.51 \\
\hline 2004 & 251,103 & 9.53 & 205,226 & 10.72 & 38,864 & 4.41 & 6,140 & 3.29 & 873 & 2.18 \\
\hline 2005 & 270,600 & 10.22 & 222,101 & 11.41 & 41,227 & 4.93 & 6,395 & 3.77 & 877 & 2.39 \\
\hline 2006 & 273,103 & 10.32 & 224,796 & 11.52 & 41,017 & 4.93 & 6,407 & 3.81 & 883 & 3.40 \\
\hline 2007 & 279,048 & 11.19 & 230,209 & 12.35 & 41,636 & 5.98 & 6,325 & 4.35 & 878 & 3.64 \\
\hline 2008 & 283,260 & 12.43 & 234,968 & 13.59 & 41,156 & 7.09 & 6,272 & 5.21 & 864 & 3.01 \\
\hline 2009 & 275,594 & 19.94 & 229,076 & 21.53 & 39,607 & 12.51 & 6,063 & 10.52 & 848 & 6.49 \\
\hline 2010 & 243,333 & 12.87 & 201,025 & 14.10 & 35,901 & 7.36 & 5,583 & 5.62 & 824 & 3.40 \\
\hline 2011 & 239,417 & 17.14 & 198,530 & 18.83 & 34,698 & 9.51 & 5,372 & 6.09 & 817 & 4.53 \\
\hline $\begin{array}{c}\text { Total } \\
(02-11)\end{array}$ & $2,593,329$ & 12.29 & $2,134,045$ & 13.54 & 390,509 & 6.53 & 60,279 & 4.87 & 8,496 & 3.37 \\
\hline
\end{tabular}

Notes: Firm shutdown takes the value 1 in $\mathrm{t}$ if the firm is last observed in that period, and 0 otherwise. Death rates are percentages of the stock of firms in year t. Firm closures are not identifiable in 2012, the last year of our sample. Own calculations based on Quadros de Pessoal, Portugal, 2002-2012. 
Table 2: Summary statistics of firm-level data (sample means)

\begin{tabular}{|c|c|c|}
\hline Variable & Mean & Std. Dev. \\
\hline Firm shutdown & 0.123 & \\
\hline \multicolumn{3}{|l|}{ Size (baseline: large) } \\
\hline Medium & 0.023 & \\
\hline Small & 0.153 & \\
\hline Micro & 0.821 & \\
\hline \multicolumn{3}{|l|}{ Period (baseline: pre-crisis) } \\
\hline Crisis (2008-2009) & 0.215 & \\
\hline Crisis (2010-2011) & 0.186 & \\
\hline Ln(sales volume) & 10.799 & 3.896 \\
\hline \multicolumn{3}{|l|}{ Ownership (baseline: private national) } \\
\hline Public & 0.002 & \\
\hline Foreign & 0.039 & \\
\hline Multi-establishment & 0.077 & \\
\hline \multicolumn{3}{|c|}{ Legal form (baseline: limited liability quota societies) } \\
\hline Personally owned - unlimited liability & 0.238 & \\
\hline Personally owned - lim. liab. quota soc. & 0.024 & \\
\hline Anonymous societies & 0.038 & \\
\hline Other & 0.057 & \\
\hline Proportion of high-skilled workers $(\%)$ & 18.294 & 30.803 \\
\hline Proportion of university graduates (\%) & 8.243 & 21.498 \\
\hline Proportion of temporary contracts $(\%)$ & 20.809 & 34.067 \\
\hline Proportion of part-timers $(\%)$ & 4.369 & 16.798 \\
\hline Proportion of women $(\%)$ & 46.651 & 41.708 \\
\hline Proportion of foreign nationals (\%) & 4.624 & 17.343 \\
\hline Mean experience in the labour market & 21.245 & 9.182 \\
\hline Mean seniority at the firm & 5.597 & 5.365 \\
\hline Mean age of employee's & 38.115 & 8.920 \\
\hline No. of observations & $2,593,084$ & \\
\hline
\end{tabular}


Table 3: Hazard estimates of firm shutdown, full sample

\begin{tabular}{|c|c|c|c|c|}
\hline & $(1)$ & $(2)$ & (3) & $(4)$ \\
\hline \multicolumn{5}{|c|}{ Firm modal size category (baseline: large) } \\
\hline \multirow[t]{2}{*}{ Medium } & $1.178 * *$ & 1.053 & $1.178 * *$ & $1.176 * *$ \\
\hline & $(0.080)$ & $(0.099)$ & $(0.087)$ & $(0.084)$ \\
\hline \multirow[t]{2}{*}{ Small } & $1.279 * * *$ & 1.151 & $1.354 * * *$ & $1.252 * * *$ \\
\hline & $(0.084)$ & $(0.103)$ & $(0.096)$ & $(0.086)$ \\
\hline \multirow[t]{2}{*}{ Micro } & $2.089 * * *$ & $2.108 * * *$ & $2.229 * * *$ & $1.994 * * *$ \\
\hline & $(0.137)$ & $(0.188)$ & $(0.158)$ & $(0.137)$ \\
\hline \multicolumn{5}{|l|}{ Time period $^{27}$} \\
\hline \multirow[t]{2}{*}{ Crisis (2008-2009) } & $1.916 * * *$ & $2.002 * * *$ & $1.592 * * *$ & \\
\hline & $(0.010)$ & $(0.282)$ & $(0.209)$ & \\
\hline \multirow[t]{2}{*}{ Crisis (2010-2011) } & $2.184 * * *$ & $2.093 * * *$ & & $1.569 * * *$ \\
\hline & $(0.015)$ & $(0.317)$ & & $(0.222)$ \\
\hline \multirow[t]{2}{*}{ Medium*Crisis (2008-2009) } & & $1.288^{*}$ & 1.231 & \\
\hline & & $(0.190)$ & $(0.169)$ & \\
\hline \multirow[t]{2}{*}{ Medium*Crisis (2010-2011) } & & 1.163 & & 1.013 \\
\hline & & $(0.185)$ & & $(0.150)$ \\
\hline \multirow[t]{2}{*}{ Small*Crisis (2008-2009) } & & 1.207 & 1.136 & \\
\hline & & $(0.171)$ & $(0.150)$ & \\
\hline \multirow[t]{2}{*}{ Small*Crisis $(2010-2011)$} & & 1.226 & & 1.079 \\
\hline & & $(0.187)$ & & $(0.153)$ \\
\hline \multirow[t]{2}{*}{ Micro*Crisis (2008-2009) } & & 0.932 & 0.926 & \\
\hline & & $(0.131)$ & $(0.122)$ & \\
\hline \multirow[t]{2}{*}{ Micro*Crisis (2010-2011) } & & 1.022 & & 0.962 \\
\hline & & $(0.155)$ & & $(0.136)$ \\
\hline \multirow[t]{2}{*}{ Constant } & $0.009 * * *$ & $0.009 * * *$ & $0.010 * * *$ & $0.010 * * *$ \\
\hline & $(0.001)$ & $(0.001)$ & $(0.001)$ & $(0.001)$ \\
\hline Log-Likelihood & $-906,222$ & $-906,050$ & $-913,006$ & $-914,912$ \\
\hline Nb. Observations & $2,593,084$ & $2,593,084$ & $2,593,084$ & $2,593,084$ \\
\hline \multicolumn{5}{|c|}{$\begin{array}{l}\text { Notes: Discrete time (cloglog) hazard model of firm shutdown with firm-leve } \\
\text { frailty. Hazard ratios reported. Further covariates relating to characteristics of the } \\
\text { firm and of the workforce, mentioned in Section } 4 \text {, were included in the } \\
\text { specification but, for the sake of space, their estimates are not shown here and are } \\
\text { provided in Table A4 in appendix. SE in parenthesis }(* \mathrm{p}<0.10, * * \mathrm{p}<0.05 \text {, *** } \\
\mathrm{p}<0.01) \text {. }\end{array}$} \\
\hline
\end{tabular}


Table 4: Hazard estimates of firm shutdown, by period

\begin{tabular}{|c|c|c|c|}
\hline & \multirow{2}{*}{$\begin{array}{c}\text { Pre-crisis } \\
\text { (1) }\end{array}$} & \multicolumn{2}{|c|}{ Crisis } \\
\hline & & $(2)$ & $(3)$ \\
\hline \multicolumn{4}{|c|}{ Firm modal size (baseline: large) } \\
\hline Medium & $\begin{array}{l}1.032 \\
(0.097)\end{array}$ & $\begin{array}{l}1.304 * * * \\
(0.113)\end{array}$ & $\begin{array}{l}1.372 * * * \\
(0.159)\end{array}$ \\
\hline Small & $\begin{array}{l}1.121 \\
(0.102)\end{array}$ & $\begin{array}{l}1.374 * * * \\
(0.115)\end{array}$ & $\begin{array}{l}1.387 * * * \\
(0.156)\end{array}$ \\
\hline Micro & $\begin{array}{l}1.968 * * * \\
(0.178)\end{array}$ & $\begin{array}{l}1.881 * * * \\
(0.158)\end{array}$ & $\begin{array}{l}1.852 * * * \\
(0.207)\end{array}$ \\
\hline \multicolumn{4}{|c|}{ Period (baseline: Crisis 2008-2009) } \\
\hline Crisis (2010-2011) & & $\begin{array}{l}1.036 * * * \\
(0.006)\end{array}$ & $\begin{array}{l}1.007 \\
(0.168)\end{array}$ \\
\hline Medium*Crisis $(2010-2011)$ & & & $\begin{array}{l}0.884 \\
(0.154)\end{array}$ \\
\hline Small*Crisis $(2010-2011)$ & & & $\begin{array}{l}0.978 \\
(0.164)\end{array}$ \\
\hline Micro*Crisis (2010-2011) & & & $\begin{array}{l}1.037 \\
(0.173)\end{array}$ \\
\hline Constant & $\begin{array}{l}0.013 * * * \\
(0.002)\end{array}$ & $\begin{array}{l}0.027 * * * \\
(0.003)\end{array}$ & $\begin{array}{l}0.027 * * * \\
(0.004)\end{array}$ \\
\hline Log-likelihood & $-478,132$ & $-427,082$ & $-427,072$ \\
\hline Nb. observations & $1,551,584$ & $1,041,500$ & $1,041,500$ \\
\hline
\end{tabular}


Table 5: Hazard estimates of firm shutdown - contemporaneous size, full sample

\begin{tabular}{|c|c|c|c|c|c|c|c|c|}
\hline & (1) & (2) & (3) & (4) & (5) & (6) & (7) & (8) \\
\hline \multicolumn{9}{|c|}{ Firm size (baseline: large) } \\
\hline Medium & $\begin{array}{l}1.176 * * \\
(0.084)\end{array}$ & $\begin{array}{l}1.078 \\
(0.110)\end{array}$ & $\begin{array}{l}1.153^{*} \\
(0.092)\end{array}$ & $\begin{array}{l}1.233 * * * \\
(0.097)\end{array}$ & $\begin{array}{l}1.179 * * \\
(0.080)\end{array}$ & $\begin{array}{l}1.090 \\
(0.109)\end{array}$ & $\begin{array}{l}1.162 * \\
(0.092)\end{array}$ & $\begin{array}{l}1.230 * * * \\
(0.095)\end{array}$ \\
\hline Small & $\begin{array}{l}1.380 * * * \\
(0.095)\end{array}$ & $\begin{array}{l}1.295 * * * \\
(0.127)\end{array}$ & $\begin{array}{l}1.397 * * * \\
(0.107)\end{array}$ & $\begin{array}{l}1.364 * * * \\
(0.103)\end{array}$ & $\begin{array}{l}1.326 * * * \\
(0.087)\end{array}$ & $\begin{array}{l}1.256^{* * *} \\
(0.120)\end{array}$ & $\begin{array}{l}1.394 * * * \\
(0.106)\end{array}$ & $\begin{array}{l}1.336 * * * \\
(0.100)\end{array}$ \\
\hline Micro & $\begin{array}{l}2.820 * * * \\
(0.195)\end{array}$ & $\begin{array}{l}2.906 * * * \\
(0.284)\end{array}$ & $\begin{array}{l}2.858 * * * \\
(0.219)\end{array}$ & $\begin{array}{l}2.639 * * * \\
(0.199)\end{array}$ & $\begin{array}{l}2.380 * * * \\
(0.157)\end{array}$ & $\begin{array}{l}2.487 * * * \\
(0.236)\end{array}$ & $\begin{array}{l}2.655 * * * \\
(0.202)\end{array}$ & $\begin{array}{l}2.364 * * * \\
(0.176)\end{array}$ \\
\hline \multicolumn{9}{|c|}{$\begin{array}{l}\text { Change in employment } \\
\text { (baseline: no change) }\end{array}$} \\
\hline Downsize & & & & & $\begin{array}{l}1.261 * * * \\
(0.006)\end{array}$ & $\begin{array}{l}1.260 * * * \\
(0.006)\end{array}$ & $\begin{array}{l}1.255^{* * * *} \\
(0.005)\end{array}$ & $\begin{array}{l}1.224 * * * \\
(0.005)\end{array}$ \\
\hline Upsize & & & & & $\begin{array}{l}0.650 * * * \\
(0.004)\end{array}$ & $\begin{array}{l}0.649 * * * \\
(0.004)\end{array}$ & $\begin{array}{l}0.642 * * * \\
(0.004)\end{array}$ & $\begin{array}{l}0.643 * * * \\
(0.004)\end{array}$ \\
\hline \multicolumn{9}{|l|}{ Period $^{28}$} \\
\hline $\begin{array}{l}\text { Crisis } \\
(2008-2009)\end{array}$ & $\begin{array}{l}1.932 * * * \\
(0.010)\end{array}$ & $\begin{array}{l}1.979 * * * \\
(0.305)\end{array}$ & $\begin{array}{l}1.497 * * * \\
(0.213)\end{array}$ & & $\begin{array}{l}1.830 * * * \\
(0.009)\end{array}$ & $\begin{array}{l}1.971 * * * \\
(0.301)\end{array}$ & $\begin{array}{l}1.585 * * * \\
(0.225)\end{array}$ & \\
\hline $\begin{array}{l}\text { Crisis } \\
(2010-2011)\end{array}$ & $\begin{array}{l}2.193 * * * \\
(0.015)\end{array}$ & $\begin{array}{l}2.349 * * * \\
(0.375)\end{array}$ & & $\begin{array}{l}1.722 * * * \\
(0.254)\end{array}$ & $\begin{array}{l}1.935 * * * \\
(0.013)\end{array}$ & $\begin{array}{l}2.080 * * * \\
(0.329)\end{array}$ & & $\begin{array}{l}1.627 * * * \\
(0.239)\end{array}$ \\
\hline $\begin{array}{l}\text { Medium*Crisis } \\
(2008-2009)\end{array}$ & & $\begin{array}{l}1.325^{*} \\
(0.213)\end{array}$ & $\begin{array}{l}1.335 * \\
(0.198)\end{array}$ & & & $\begin{array}{l}1.285 \\
(0.205)\end{array}$ & $\begin{array}{l}1.309 * \\
(0.194)\end{array}$ & \\
\hline $\begin{array}{l}\text { Medium*Crisis } \\
(2010-2011)\end{array}$ & & $\begin{array}{l}0.987 \\
(0.166)\end{array}$ & & $\begin{array}{l}0.844 \\
(0.131)\end{array}$ & & $\begin{array}{l}0.981 \\
(0.164)\end{array}$ & & $\begin{array}{l}0.863 \\
(0.134)\end{array}$ \\
\hline $\begin{array}{l}\text { Small*Crisis } \\
(2008-2009)\end{array}$ & & $\begin{array}{l}1.210 \\
(0.188)\end{array}$ & $\begin{array}{l}1.213 \\
(0.173)\end{array}$ & & & $\begin{array}{l}1.169 \\
(0.180)\end{array}$ & $\begin{array}{l}1.188 \\
(0.170)\end{array}$ & \\
\hline $\begin{array}{l}\text { Small*Crisis } \\
(2010-2011)\end{array}$ & & $\begin{array}{l}1.033 \\
(0.166)\end{array}$ & & $\begin{array}{l}0.921 \\
(0.136)\end{array}$ & & $\begin{array}{l}1.030 \\
(0.164)\end{array}$ & & $\begin{array}{l}0.949 \\
(0.140)\end{array}$ \\
\hline $\begin{array}{l}\text { Micro*Crisis } \\
(2008-2009)\end{array}$ & & $\begin{array}{l}0.955 \\
(0.147)\end{array}$ & $\begin{array}{l}0.994 \\
(0.141)\end{array}$ & & & $\begin{array}{l}0.908 \\
(0.139)\end{array}$ & $\begin{array}{l}0.961 \\
(0.137)\end{array}$ & \\
\hline $\begin{array}{l}\text { Micro*Crisis } \\
(2010-2011)\end{array}$ & & $\begin{array}{l}0.924 \\
(0.148)\end{array}$ & & $\begin{array}{l}0.885 \\
(0.130)\end{array}$ & & $\begin{array}{l}0.921 \\
(0.146)\end{array}$ & & $\begin{array}{l}0.915 \\
(0.135)\end{array}$ \\
\hline Constant & $\begin{array}{l}0.007 * * * \\
(0.001)\end{array}$ & $\begin{array}{l}0.007 * * * \\
(0.001)\end{array}$ & $\begin{array}{l}0.008 * * * \\
(0.001)\end{array}$ & $\begin{array}{l}0.008 * * * \\
(0.001)\end{array}$ & $\begin{array}{l}0.010 * * * \\
(0.001)\end{array}$ & $\begin{array}{l}0.010 * * * \\
(0.001)\end{array}$ & $\begin{array}{l}0.007 * * * \\
(0.001)\end{array}$ & $\begin{array}{l}0.008 * * * \\
(0.001)\end{array}$ \\
\hline Log-Likelihood & $-903,690$ & $-903,566$ & $-910,526$ & $-912,569$ & $-898,416$ & $-898,270$ & $-904,179$ & $-906,882$ \\
\hline
\end{tabular}

Notes: Discrete time (cloglog) hazard model of firm shutdown, with firm-level frailty. Hazard ratios reported. All models have the same number of observations: 2,593,084. Further covariates relating to characteristics of the firm and of the workforce, mentioned in Section 4, were included in the specification but, for the sake of space, their estimates are not shown here and are provided in Table A3 in appendix. SE in parenthesis $(* \mathrm{p}<0.10, * * \mathrm{p}<0.05$, $* * * \mathrm{p}<0.01)$. 
Table 6: Hazard estimates of firm shutdown, by period

\begin{tabular}{|c|c|c|c|c|c|c|}
\hline & \multirow{2}{*}{$\frac{\text { Pre-crisis }}{(1)}$} & \multicolumn{2}{|c|}{ Crisis } & \multirow{2}{*}{$\frac{\text { Pre-crisis }}{(4)}$} & \multicolumn{2}{|c|}{ Crisis } \\
\hline & & (2) & (3) & & $(5)$ & $(6)$ \\
\hline \multicolumn{7}{|l|}{ Firm size (baseline: large) } \\
\hline Medium & $\begin{array}{l}1.066 \\
(0.110)\end{array}$ & $\begin{array}{l}1.275^{* * * *} \\
(0.117)\end{array}$ & $\begin{array}{l}1.458 * * * \\
(0.183)\end{array}$ & $\begin{array}{l}1.071 \\
(0.106)\end{array}$ & $\begin{array}{l}1.279 * * * \\
(0.117)\end{array}$ & $\begin{array}{l}1.432 * * * \\
(0.179)\end{array}$ \\
\hline Small & $\begin{array}{l}1.253^{* *} \\
(0.124)\end{array}$ & $\begin{array}{l}1.407 * * * \\
(0.125)\end{array}$ & $\begin{array}{l}1.532 * * * \\
(0.186)\end{array}$ & $\begin{array}{l}1.218^{* *} \\
(0.116)\end{array}$ & $\begin{array}{l}1.409 * * * \\
(0.125)\end{array}$ & $\begin{array}{l}1.495 * * * \\
(0.182)\end{array}$ \\
\hline Micro & $\begin{array}{l}2.660 * * * \\
(0.263)\end{array}$ & $\begin{array}{l}2.448 * * * \\
(0.216)\end{array}$ & $\begin{array}{l}2.549 * * * \\
(0.309)\end{array}$ & $\begin{array}{l}2.266 * * * \\
(0.215)\end{array}$ & $\begin{array}{l}2.308 * * * \\
(0.204)\end{array}$ & $\begin{array}{l}2.324 * * * \\
(0.282)\end{array}$ \\
\hline \multicolumn{7}{|l|}{$\begin{array}{l}\text { Change in employment } \\
\text { (baseline: no change) }\end{array}$} \\
\hline Downsize & & & & $\begin{array}{l}1.305^{* * * *} \\
(0.008)\end{array}$ & $\begin{array}{l}1.278 * * * \\
(0.007)\end{array}$ & $\begin{array}{l}1.278 * * * \\
(0.007)\end{array}$ \\
\hline Upsize & & & & $\begin{array}{l}0.634 * * * \\
(0.006)\end{array}$ & $\begin{array}{l}0.658 * * * \\
(0.006)\end{array}$ & $\begin{array}{l}0.658 * * * \\
(0.006)\end{array}$ \\
\hline \multicolumn{7}{|c|}{ Period (baseline: Crisis 2008-2009) } \\
\hline Crisis (2010-2011) & & $\begin{array}{l}1.030 * * * \\
(0.006)\end{array}$ & $\begin{array}{l}1.135 \\
(0.199)\end{array}$ & & $\begin{array}{l}1.020 * * * \\
(0.006)\end{array}$ & $\begin{array}{l}1.045 \\
(0.183)\end{array}$ \\
\hline Medium*Crisis (2010-2011) & & & $\begin{array}{l}0.728 * \\
(0.134)\end{array}$ & & & $\begin{array}{l}0.760 \\
(0.139)\end{array}$ \\
\hline Small*Crisis $(2010-2011)$ & & & $\begin{array}{l}0.826 \\
(0.145)\end{array}$ & & & $\begin{array}{l}0.874 \\
(0.154)\end{array}$ \\
\hline Micro*Crisis (2010-2011) & & & $\begin{array}{l}0.918 \\
(0.161)\end{array}$ & & & $\begin{array}{l}0.988 \\
(0.173)\end{array}$ \\
\hline Constant & $\begin{array}{l}0.010 * * * \\
(0.001)\end{array}$ & $\begin{array}{l}0.023 * * * \\
(0.003)\end{array}$ & $\begin{array}{l}0.022 * * * \\
(0.003)\end{array}$ & $\begin{array}{l}0.014 * * * \\
(0.002)\end{array}$ & $\begin{array}{l}0.020 * * * \\
(0.002)\end{array}$ & $\begin{array}{l}0.020 * * * \\
(0.003)\end{array}$ \\
\hline Log-likelihood & $-477,029$ & $-425,853$ & $-425,830$ & $-474,107$ & $-422,556$ & $-422,526$ \\
\hline Nb. observations & $1,551,584$ & $1,041,500$ & $1,041,500$ & $1,551,584$ & $1,041,500$ & $1,041,500$ \\
\hline
\end{tabular}

Notes: Discrete time (cloglog) hazard models of firm shutdown with firm-level frailty. Hazard ratios reported. Further covariates relating to characteristics of the firm and of the workforce, mentioned in Section 4 were included in the specification but their estimates are not shown. SE in parenthesis (* $\mathrm{p}<0.10, * * \mathrm{p}<0.05, * * * \mathrm{p}<0.01)$. 


\section{Appendix}

Table A.1: Correlations between explanatory variables

\begin{tabular}{|c|c|c|c|c|c|c|c|c|}
\hline \multicolumn{9}{|c|}{ Panel A: Firm characteristics } \\
\hline & Shutdown & Size & Time & $\ln ($ sales $)$ & Plant age & Ownership & Multiplant & Legal Form \\
\hline Shutdown & 1.0000 & & & & & & & \\
\hline Size & 0.0954 & 1.0000 & & & & & & \\
\hline Time & 0.0713 & 0.0080 & 1.0000 & & & & & \\
\hline $\ln ($ sales $)$ & -0.1242 & -0.2555 & 0.0626 & 1.0000 & & & & \\
\hline Plant age & -0.0857 & -0.1970 & 0.0646 & 0.2121 & 1.0000 & & & \\
\hline Ownership & 0.0198 & -0.0527 & 0.2522 & 0.0202 & 0.0318 & 1.0000 & & \\
\hline Multiplant & -0.0397 & -0.2689 & 0.0800 & 0.1239 & 0.1032 & 0.0584 & 1.0000 & \\
\hline Legal Form & 0.0015 & -0.1198 & 0.0612 & -0.1571 & 0.1351 & 0.1413 & 0.0608 & 1.0000 \\
\hline
\end{tabular}

Panel B: Workforce characteristics

\begin{tabular}{|c|c|c|c|c|c|c|c|c|c|}
\hline & Shutdown & $\begin{array}{c}\% \text { High } \\
\text { skill }\end{array}$ & $\begin{array}{l}\% \text { Uni. } \\
\text { Grads }\end{array}$ & $\begin{array}{c}\% \text { Fixed } \\
\text { term }\end{array}$ & $\begin{array}{l}\% \text { Part } \\
\text { Time }\end{array}$ & $\begin{array}{c}\% \\
\text { Women } \\
\end{array}$ & $\begin{array}{c}\% \\
\text { Foreign } \\
\end{array}$ & $\begin{array}{l}\text { Mean } \\
\text { Exper. }\end{array}$ & $\begin{array}{l}\text { Mean } \\
\text { Tenure }\end{array}$ \\
\hline Shutdown & 1.0000 & & & & & & & & \\
\hline$\%$ High skill & 0.0020 & 1.0000 & & & & & & & \\
\hline$\%$ Uni. Grads & -0.0071 & 0.4477 & 1.0000 & & & & & & \\
\hline$\%$ Fixed term & 0.0418 & -0.0592 & 0.0112 & 1.0000 & & & & & \\
\hline$\%$ Part Time & 0.0235 & 0.0143 & 0.0577 & 0.0464 & 1.0000 & & & & \\
\hline$\%$ Women & 0.0098 & 0.0070 & 0.0648 & 0.0457 & 0.1174 & 1.0000 & & & \\
\hline$\%$ Foreign Nationals & 0.0434 & -0.0463 & -0.0223 & 0.2117 & 0.0236 & -0.0261 & 1.0000 & & \\
\hline Mean Experience & 0.0136 & 0.0129 & -0.1770 & -0.1405 & 0.0625 & -0.0285 & -0.0409 & 1.0000 & \\
\hline Mean Tenure & -0.0692 & 0.0425 & -0.0577 & -0.2876 & -0.0208 & -0.0162 & -0.1285 & 0.3929 & 1.0000 \\
\hline
\end{tabular}

Note: correlations based on the estimation sample.

Table A.2: Transition matrix of firm size categories

\begin{tabular}{lcccc}
\hline Size & Large & Medium & Small & Micro \\
\hline Large & 91.80 & 7.57 & 0.40 & 0.23 \\
Medium & 1.17 & 89.45 & 8.76 & 0.61 \\
Small & 0.01 & 1.53 & 87.23 & 11.24 \\
Micro & 0.00 & 0.02 & 2.22 & 97.76 \\
\hline
\end{tabular}

Note: own calculations based on the estimation sample. 
Table A.3: Hazard estimates of firm shutdown, alternative specification of the crisis period (2008-2011)

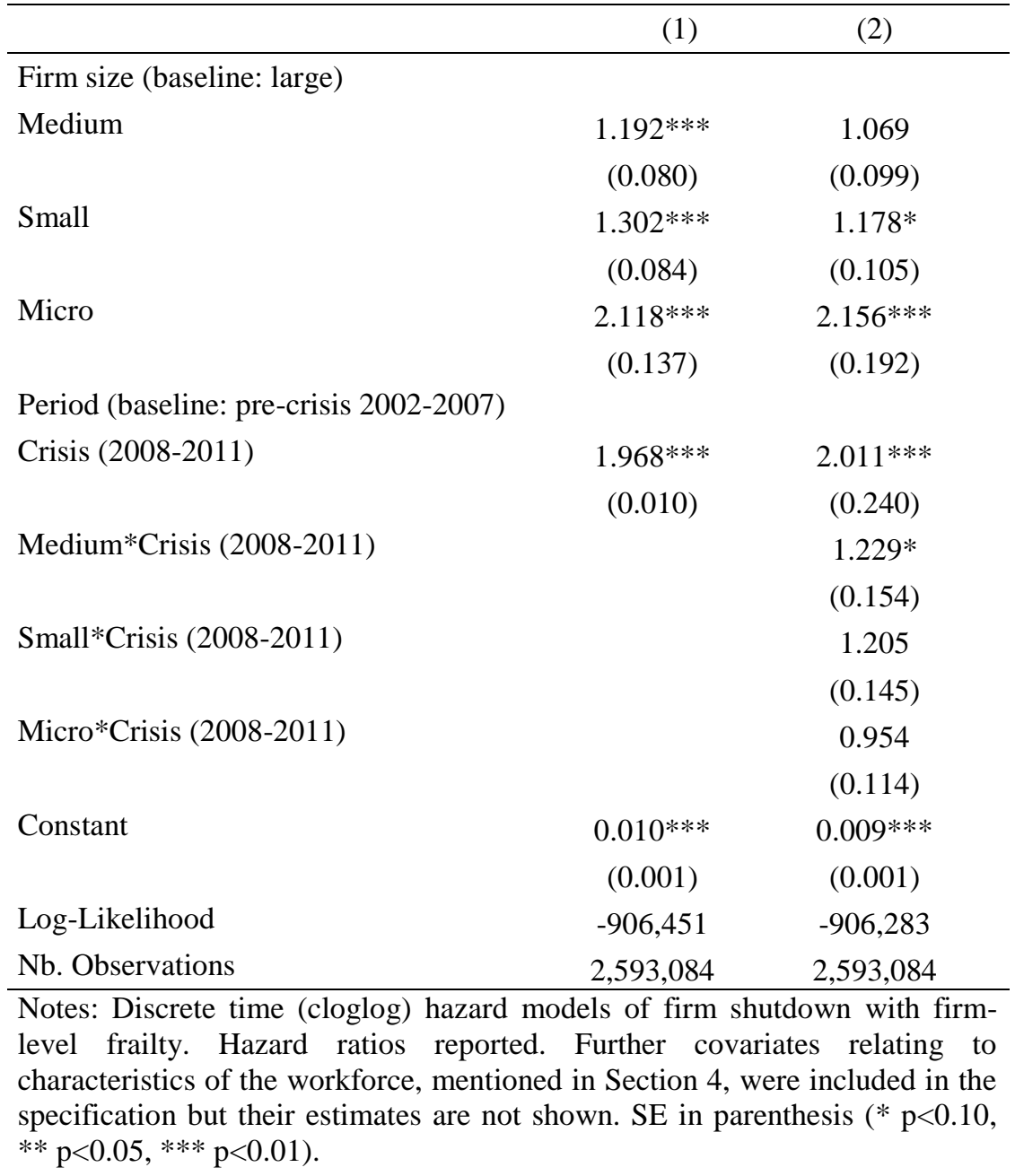


Table A.4: Hazard estimates of firm shutdown, full sample (Table 3 ctd.)

\begin{tabular}{|c|c|c|c|c|}
\hline & (1) & (2) & (3) & (4) \\
\hline \multirow[t]{2}{*}{ Ln(sales volume) } & $0.939 * * *$ & $0.939 * * *$ & $0.944 * * *$ & $0.942 * * *$ \\
\hline & $(0.001)$ & $(0.001)$ & $(0.000)$ & $(0.000)$ \\
\hline \multicolumn{5}{|c|}{ Ownership (Baseline: private national) } \\
\hline \multirow[t]{2}{*}{ Public } & $0.583 * * *$ & $0.582 * * *$ & $0.625 * * *$ & $0.588 * * *$ \\
\hline & $(0.043)$ & $(0.043)$ & $(0.042)$ & $(0.040)$ \\
\hline \multirow[t]{2}{*}{ Foreign } & $0.940 * * *$ & $0.944 * * *$ & $1.330 * * *$ & $0.941 * * *$ \\
\hline & $(0.009)$ & $(0.009)$ & $(0.012)$ & $(0.009)$ \\
\hline \multirow[t]{2}{*}{ Multiplant firm } & $0.755 * * *$ & $0.755 * * *$ & $0.830 * * *$ & $0.773 * * *$ \\
\hline & $(0.007)$ & $(0.007)$ & $(0.007)$ & $(0.007)$ \\
\hline \multicolumn{5}{|c|}{ Legal form (Baseline: quota societies) } \\
\hline \multirow[t]{2}{*}{ Individual name } & $1.860 * * *$ & $1.856 * * *$ & $1.672 * * *$ & $1.724 * * *$ \\
\hline & $(0.010)$ & $(0.010)$ & $(0.008)$ & $(0.008)$ \\
\hline \multirow[t]{2}{*}{ Unipersonal quota soc. } & $1.066 * * *$ & $1.068 * * *$ & $1.697 * * *$ & $1.098 * * *$ \\
\hline & $(0.012)$ & $(0.012)$ & $(0.017)$ & $(0.012)$ \\
\hline \multirow[t]{2}{*}{ Anonymous society } & 1.017 & 1.011 & 1.011 & 1.012 \\
\hline & $(0.014)$ & $(0.014)$ & $(0.013)$ & $(0.013)$ \\
\hline \multirow[t]{2}{*}{ Other } & $1.069 * * *$ & $1.068 * * *$ & $1.023 * *$ & $1.034 * * *$ \\
\hline & $(0.011)$ & $(0.011)$ & $(0.010)$ & $(0.010)$ \\
\hline \multirow[t]{2}{*}{$\%$ of high skilled } & $1.002 * * *$ & $1.002 * * *$ & $1.002 * * *$ & $1.002 * * *$ \\
\hline & $(0.000)$ & $(0.000)$ & $(0.000)$ & $(0.000)$ \\
\hline \multirow[t]{2}{*}{$\%$ University graduates } & $0.996 * * *$ & $0.996 * * *$ & $0.996 * * *$ & $0.996 * * *$ \\
\hline & $(0.000)$ & $(0.000)$ & $(0.000)$ & $(0.000)$ \\
\hline \multirow[t]{2}{*}{$\%$ Fixed term contracts } & $1.002 * * *$ & $1.002 * * *$ & $1.002 * * *$ & $1.002 * * *$ \\
\hline & $(0.000)$ & $(0.000)$ & $(0.000)$ & $(0.000)$ \\
\hline \multirow[t]{2}{*}{$\%$ Part-time workers } & $1.001 * * *$ & $1.001 * * *$ & $1.002 * * *$ & $1.002 * * *$ \\
\hline & $(0.000)$ & $(0.000)$ & $(0.000)$ & $(0.000)$ \\
\hline \multirow[t]{2}{*}{$\%$ Women } & $1.001 * * *$ & $1.001 * * *$ & $1.001 * * *$ & $1.001 * * *$ \\
\hline & $(0.000)$ & $(0.000)$ & $(0.000)$ & $(0.000)$ \\
\hline \multirow[t]{2}{*}{$\%$ Foreign nationals } & $1.003 * * *$ & $1.003 * * *$ & $1.003 * * *$ & $1.003 * * *$ \\
\hline & $(0.000)$ & $(0.000)$ & $(0.000)$ & $(0.000)$ \\
\hline \multirow[t]{2}{*}{ Mean experience in LM } & $0.945 * * *$ & $0.945 * * *$ & $0.930 * * *$ & $0.924 * * *$ \\
\hline & $(0.003)$ & $(0.003)$ & $(0.003)$ & $(0.003)$ \\
\hline \multirow[t]{2}{*}{ Mean seniority at firm } & $0.996 * * *$ & $0.996 * * *$ & $0.993 * * *$ & $0.994 * * *$ \\
\hline & $(0.001)$ & $(0.001)$ & $(0.001)$ & $(0.001)$ \\
\hline \multirow[t]{2}{*}{ Mean age } & $1.071 * * *$ & $1.072 * * *$ & $1.089 * * *$ & $1.097 * * *$ \\
\hline & $(0.004)$ & $(0.004)$ & $(0.003)$ & $(0.003)$ \\
\hline
\end{tabular}

Note: As in Table 3. 
Table A.5: Predicted hazard of firm shutdown, by time period and firm size

\begin{tabular}{lccc|c}
\hline & Pre-crisis & Financial Crisis & Sovereign Debt Crisis & Overall \\
\hline Large & 0.022 & 0.044 & 0.038 & 0.030 \\
Medium & 0.029 & 0.073 & 0.059 & 0.044 \\
Small & 0.045 & 0.098 & 0.092 & 0.064 \\
Micro & 0.104 & 0.182 & 0.184 & 0.136 \\
\hline Overall & 0.093 & 0.166 & 0.167 & 0.122 \\
\hline \multicolumn{2}{l}{ Note: Hazards were predicted after estimating model (2) in Table 3 }
\end{tabular}

\section{Figures}

Figure 1: The Portuguese Business Cycle (2000-2014) and the Diffusion Index on banks' credit standards

$<$ Figure1_cycle_di.wmf $>$

Figure 2: The demography of Portuguese firms (all active companies)

<Figure2_firmdem.wmf>

Figure 3: Estimated pattern of duration dependence

<Figure3_haz.wmf>

Figure A.1: Active companies and number of deaths - estimation sample

<FigureA1_firmdemQP.wmf> 


\section{Endnotes}

${ }^{\dagger}$ Corresponding author: Department of Economics, School of Economics and Management, University of Minho, Campus de Gualtar, 4710-057 Braga, Portugal. Phone: +351 253601 938. Email:

Priscila@eeg.uminho.pt.

* Small Business Research Centre (SBRC), Kingston Business School, Kingston Hill Campus, Kingston Hill Kingston upon Thames, KT2 7LB, UK. Phone: +44 (0)20 8417 5347. Email G.Saridakis@ @ingston.ac.uk

${ }^{1} 2012$ is the most recent year for which the data set has been made available. Between 1994 and 2002 the Portuguese business cycle is described by one single phase of economic expansion.

${ }^{2}$ The turning points of the series were identified applying NBER's methodology (Bry and Boschan, 1971) to quarterly data, as suggested by Harding and Pagan (2002), using Stata routine -sbbq- by Bracke (2011).

${ }^{3}$ Bank Lending Survey (Bank of Portugal, 2013). The Bank Lending Survey started being collected in January 2003 and ended in April 2013, the purpose of this survey was to enhance the understanding of bank lending behaviour in the euro area. The survey is composed of 18 questions. The diffusion index reported here is that related to Question 1 of the Bank Lending Survey for the Eurozone: "Over the past three months, how have your bank's credit standards as applied to the approval of loans or credit lines to enterprises changed?". The diffusion index is the weighted difference between the share of banks reporting that credit standards have been tightened and the share of banks reporting that they have been eased. A positive net percentage indicates that a larger proportion of banks have tightened credit standards ("net tightening"), whereas a negative net percentage indicates that a larger proportion of banks have eased credit standards ("net easing").

${ }^{4}$ According to Eurostat (2015) metadata a firm death amounts to the dissolution of a combination of production factors with the restriction that no other firms are involved in the event. Deaths do not include exits from the population due to mergers, take-overs, break-ups or restructuring of a set of firms. Also, it does not include exits from a sub-population resulting only from a change of activity.

${ }^{5}$ Similar patterns of firm entry and exit over the business cycle were found by Huynh et al. (2010), using data for Canadian manufacturing firms (1985-1997); and by Lee and Mukoyama (2015), for a sample of manufacturing firms (1972-1997) in the USA.

${ }^{6}$ QP data were not collected in 2001, hence our analysis starts in 2002; 2012 is the most recent year for which the data set has been built.

${ }^{7}$ We exclude the primary sector (agriculture, fishing, extraction) as most firms are family businesses and coverage of this sector in the QP data is small.

${ }^{8}$ Given that the QP panel ends in 2012, the number of firm deaths in 2011 are identified from a one-year window. Hence, firm closures for 2011 resemble the temporary statistics reported by the ONS (death events are usually definite after a two-year window). This can generate a slight over-estimate of the number of firm closures in the last year of our sample. We are not able to identify the reason why firms close.

9 In Figure A.1 in appendix we plot the number of active firms and firm deaths based on our estimation sample (QP data - firms with registered employees) and find that the pattern on the stock of firms and number of firm deaths is similar to that reported earlier in Figure 2 (using Eurostat's Business Demography data that considers all active firms, regardless of having registered employees) the stock of firms increases until 2008 and declines thereafter; firm closures soar in 2008.

${ }^{10} \mathrm{We}$ use this discrete time representation of a continuous time proportional hazards model because our data are interval censored. That is, we know the firm leaves the panel between $t$ and $t+1$ (last observed in $t$ ) but we do not know the exact date when this event occurs.

11 Firm size is measured as the number of employees working at the firm. Firms are grouped into four categories of size, following the European Recommendation 2003/361: (i) micro, if they employ less than 10 workers; (ii) small, if they employ more than 9 and less than 50 workers; (iii) medium, if they employ more than 49 and less than 250 workers; and are (iv) large, if the employ more than 249 workers.

${ }^{12}$ Huynh et al. (2012) have shown that firms' initial financial conditions are relevant factors affecting their survival prospects. However, our data does not have firms' financial information, hence the effect of these variables is likely to be captured as unobserved heterogeneity.

${ }^{13}$ Firms are requested to classify workers into nine skill levels according to the complexity and responsibility of the tasks performed; we group these into three categories: high, medium and low skilled workers.

14 The average rate of firm closures over the period of analysis is $12 \%$. Smaller firms dominate the market with $97 \%$ of the firms in this sample being micro (less than 10 workers) or small firms (with 10 to 49 employees). The average sales volume is about 49 thousand euros $(\exp (\ln (10.799))$. About $4 \%$ of the firms are foreign owned, and $8 \%$ has more than one establishment. Regarding the covariates that proxy for human capital accumulation, workers' mean potential labour market experience is 22 years, while mean seniority in the firm is nearly 6 years. On average, the composition of the firm's labour force involves $18 \%$ of high 
skilled workers and $8 \%$ of university graduates. Considering our proxies on the stability of the labour force, on average $21 \%$ of the firms' workforce is employed with temporary contracts, $4 \%$ are part-timers, and $47 \%$ are women. In Table A1 in appendix we show correlations between the explanatory variables.

15 Table A2 in appendix reports the firms' size transition patterns over the period of analysis. The sample contains 525,733 firms. In $98.5 \%$ of the cases, the mode was identified as the most observed size category. For the remaining $1.5 \%$ of the firms: (i) in $97 \%$ of the cases the size distribution was bimodal, and the mode was defined as the first observed modal size category; (ii) in $3 \%$ of the cases the mode was identified by the size category observed in more than $1 / 3$ of the firm-year observations.

${ }^{16}$ We cannot reject the hypothesis that the main effects of the time periods are statistically equal to those obtained in column 1.

${ }^{17}$ We have tested the joint significance of the firm size variables and also performed a joint test that all coefficients associated with the interactions between time period and size are zero. All covariates are jointly statistically significant with a p-value below $1 \%$.

${ }^{18}$ Following the strategy by Varum and Rocha (2012) we have estimated a model combining the effect of the two crises. These results confirm that smaller firms are more likely to shutdown than larger firms. We also find that the hazard for firm shutdown during the combined crisis period is nearly twice that of the pre-crisis period. The interactions with the firm size provide support for the result on the increased risk of closing of medium sized firms during crisis (see Table A3 in appendix).

${ }^{19}$ We also examine whether the firm size results are affected by the exclusion of the $\log ($ sales volume). Excluding this variable makes little difference in the results reported here, with an exception for the interaction term of small firms with the Sovereign Debt Crisis where we find a positive and significant coefficient (these results are available upon request). The best fitting models (larger log-likelihood) are those that include controls for the firms' sales volume.

${ }^{20}$ These results are in line with previous work, e.g. Mata and Portugal (1994), Pakes and Ericson (1995), Huynh and Petrunia (2016)

${ }^{21}$ We have tested the hypothesis that each coefficient of size of the models in columns (2) and (3) of Table 4 are equal to the estimated parameter of the firms modal size category in column (1). We reject the hypothesis that the coefficients of medium and small firms in columns (2) and (3) are equal to the estimated parameters in column (1).

${ }^{22}$ The variable "Change in employment" reports firm level changes in the number of employees between $\mathrm{t}-1$ and $t$ and takes the values: 0 if no change; 1 if the number of employees decreased; and 2 if the number of employees increased.

${ }^{23}$ We cannot reject the hypothesis that the main effects of the size categories, change in employment, and time periods are statistically equal to those obtained in column 5 .

${ }^{24}$ We have tested the joint significance of the firm size variables and also performed a joint test that all coefficients associated with the interactions between time period and size are zero. All covariates are jointly statistically significant with a p-value below $1 \%$.

${ }^{25}$ We have tested the hypothesis that each coefficient of size of the models in columns (2) and (3) of Table 6 are equal to the estimated parameter of firm size in column (1). For the specification in column (2) we reject the hypothesis that the estimated coefficient of medium sized firms is equal to the estimated parameter in column (1). We also reject the hypothesis that the coefficients of medium and small firms in column (3) are equal to the estimated parameters in column (1).

${ }^{26}$ A further interesting test to the robustness of our results is the study of differences in the determinants of survival rates of firms created during the Financial Crisis and of firms created during the Sovereign Debt crisis. Unfortunately, our data does not have enough time periods (it ends in 2012, as of yet) to perform this sort of analysis properly.

${ }^{27}$ In columns 1 and 2 the baseline is the pre-crisis period, in column 3 the Financial Crisis period is contrasted with all other observations, while in column 4 the Sovereign Debt Crisis period is contrasted with all other observations.

${ }^{28}$ In columns (1), (2), (5) and (6) the baseline is the pre-crisis period; in columns (3) and (7) the Financial Crisis period is contrasted with all other observations; in columns (4) and (8) the Sovereign Debt Crisis period is contrasted with all other observations. 